\title{
Women on Boards as a Mechanism to Improve Carbon Emission Disclosure and Firm Value
}

AFFILIATION:

1,2,3 Faculty of Economics and Business, University of Atma Jaya Makassar, Indonesia

\section{*CORRESPONDENCE:}

fedaromes@gmail.com

THIS ARTICLE IS AVAILABLE IN:

https://ojs.unud.ac.id/index.php/jiab

DOI:

10.24843/JIAB.2021.v16.i02.p11

\section{CITATION:}

Monica, M., Daromes, F. E., \& Ng, S. (2021). Women on Boards as a Mechanism to Improve Carbon Emission Disclosure and Firm Value. Jurnal IImiah Akuntansi dan Bisnis, 16(2), 343-358.

\section{ARTICLE HISTORY}

Received:

04 January 2021

Revised:

07 June 2021

\section{Accepted:}

30 June 2021

\author{
Monica ${ }^{1}$, Fransiskus Eduardus Daromes ${ }^{2 *}$, Suwandi $\mathrm{Ng}^{3}$
}

\begin{abstract}
This study investigates the role of women on boards as a mechanism to improve carbon emission disclosure, as a mediating effect influence on firm value. The population includes 122 nonfinancial companies listed on the Indonesia Stock Exchange from 2015 to 2019. The results of path analysis reveal that women on boards have a positive and significant effect on carbon emission disclosure, a positive but insignificant effect on firm value, and that carbon emission disclosure is pivotal in mediating women on boards and firm value. This study provides insights that persuade companies to maintain relationships with stakeholders by implementing environmental awareness and disclosing sustainability reports. Carbon emission disclosure as part of the sustainability report is a form of good corporate action in maintaining the balance of living systems on earth.
\end{abstract}

Keywords: women on boards, carbon emissions disclosure, firm value

\section{Introduction}

Firm value plays an important value to a company, which by the increase of it, so as the prosperity of the stockholders, eventually as the main goal of the company itself (Kelvin et al., 2017). High firm value is not depicted solely by the profitability of the company, rather it should be combined by economic performance, the concern on the social justice, and the company responsibility towards sustainability. Companies that lean toward the sustainability of environment will get a bigger attention for the option of investing by the investors due to an increasing concern on proecological and sustainability movements.

Carbon emissions disclosure may be assessed as an act of seriousness to the ecological issues. The disclosure includes the intensity of the carbon emissions, energy usage, strategies on handling the climate change, actions toward reducing carbon emissions, and the riskopportunity management on the impact of climate change (Rashid, 2018). Inline to Indonesian government regulations, there are several fields regarding on information disclosure, such as Presidential Decree No. 61 on National Act of Greenhouse Gas Emission Decreasing Plan 2011, Government Regulations No. 79 on National Energy Policy 2014, 
Presidential Decree No. 22 on National Energy General Plan 2017, and Act No. 16 on the Endorsement of Paris Agreement to the United Nations Framework Convention on Climate Change 2016. The government invites businessmen to support the efforts on handling the climate change due to the requirements of commitment and sustaining actions on it. Hollindale et al. (2019) stated that the company's decision on exercising the disclosure is depending on the role of the top management. The gender diversity on the direction board is said to have a positive effect on every policy made by the company as there will be a lot of perspective alternatives when it comes to decision making. Solikhah (2020) also stated that the similar thing will also increase the quality of discussions and the ability of the direction board to serve a better view in the company's reporting and disclosure.

This research is a development of one that was conducted by Hollindale et al. (2019) by placing the carbon emission disclosure as the intervening variable which mediating the influence of women on boards upon the firm value. The presence of women in the board of directors tends to generate a broader variety of ideas and innovation (Mirza et al., 2020) that leads to a better decision making quality both individual and organizational. It also helps and promotes the mechanism of carbon emission disclosure, affects to the effectivity of the communications between the directors and the investors, brings a tighter control by serving a more transparent ecological disclosure (Olthuis \& Oever, 2020). This mechanism eventually will encourage the firm value. The importance of this research concerns as much to the worried environmental issues. Carbon emission disclosure is hoped to produce a sustaining support from the stakeholder, especially those indirectly involved. Women's character on the board of directors makes the decision making to be the carefully and risk avoding conducted one, resulting to a good quality disclosure which heavily affect the firm value.

The Theory of Stakeholder explains the relationship between the firm and the stakeholder which affects or is affected by the company's activities, targets, and corresponding decisions. Stakeholder's components that should be the firm's concern were emphasized by the Gaia theory, coined by Lovelock (1979), it stated that the company and components of the Earth should nurture, maintain, and conserve the environment, which is not solely for the sake of human being, but for the other elements as well (i.e. land, air, sea, and all of their living and non-living elements).

One such action for the company to pay its attention towards the stakeholders is to provide informations about the company's activities. The environment, society, and the future generations as stakeholders have their own right to be provided such informations for the purpose of the decision making process (Zsolnai, 2006). A well managed relationship between the firm and the stakeholders will secure the firm's sustainability in the future. Ahmad \& Hossain (2015) stated that through the informations and disclosure of the firm's carbon emission on the annual statement, the stakeholders will be able to comprehend the company's policy, value, and motive to handle the carbon emission generated. Such action will gain a specific value for the company Hollindale et al. (2019).

The company's decision to make wider disclosures is motivated by the role of top management. The presence of women on the board of directors is less aggressive, more cautious, and tends to avoid the risk of having an impact on the carbon emissions disclosure by the company as a means of revealing stakeholder trust in the company. Hollindale et al. (2019) found that companies that have women on their boards have 
greater potential to produce better quality disclosures related to greenhouse gas emissions in their annual reports and corporate sustainability. Companies that have female directors make the resulting disclosures softer, including information related to the vision and mission, environmental profiles, and environmental initiatives so as to increase the market price of the company's stock.

Byron \& Post (2016) stated that the existence of women in the directors' board will affect the carbon emission disclosure positively. Liao et al. (2015) also found that women on boards will increase the possibility of a more qualified gas emission disclosure because they tend to concern more on the life quality rather than material earnings. But, the research of Nainggolan \& Rohman (2015) resulted on a different outcome that women on boards element doesn't have a significant effect on the carbon emission disclosure.

Stakeholder theory emphasized on how firm should not operate on the entity's personal gain or profit but also benefits the stakeholders. The firm's life is heavily affected by the stakeholder's support (Hitipeuw \& Kuntari, 2020). Although the directors' board is not involved personally on the years of environment's devastation, they still got a dirty hand. They should be responsible for the actions of restoring the Earth through generating policies.

Social and environment disclosure are very well depended on the top management decisions. That means, the disclosures done are not always might be guaranteed to be on the line with the firm's visions and missions. If the firm's leaders are of a good moral, the disclosures done might be a comprehensive one, vice versa (Solikhah, 2020). Women's role on the directors' board will direct to the more transparent and broad disclosure on the carbon emission. Thus, such hypotheses are composed:

$\mathrm{H}_{1}$ : Women on boards has a significant effect on the carbon emission's disclosure.

Stakeholder theory considers the relationship between the company and their stakeholders (Horisch et al., 2020). Carbon emission disclosure may maintain a reasonable relationship of both parties as it marks the commitment and concern to the environmental issues.

Lovelock \& Watson (1982) through their Gaia theory stated that the Earth's life system has risen the 'red light' warning about the earth's immunity system has been pushed to the edge. The high content of $\mathrm{CO} 2$ and the green house's substances are on the state of not being able to be quickly reduced by the plants and phytoplankton. Thus, the disclosure on the carbon emission is the sign of the company's seriousness and commitment on maintaining the ecological sustainability (Rashid, 2018).

H3

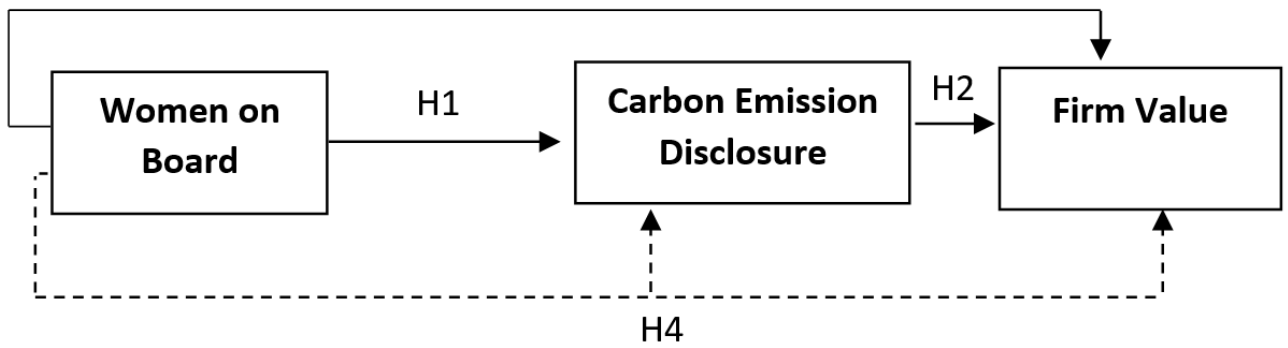

Figure 1. Theoretical Framework

Source: Processed Data, 2020 
The carbon emissions disclosure helps the investors to identify the risk potentials of the company's future and evaluate the alternatives of the strategies to endure the hurdles may have generated. The high amount of company's disclosures bears the message of a good economic performance due to the efficiency actions such as replacement of machines. By then, such information will provide a form of measurement of the company's operational value through the identification of sustainable management that will generate a higher firm value. Thus, such hypothesis is provided:

$\mathrm{H}_{2}$ : Carbon emission disclosure has a significant effect to the firm value.

Orazalin \& Baydauletov (2020) and Nadeem et al. (2017) found that the more women involved in the directors' board, the denser the amount of the decision making process and the effectivity of the board. Women's representative in the director's board generally increase the firm value through social performances and reducing the negative activities in the broader context marked by providing some kind of protection for the stakeholders. This research emphasized to the analysis on how a woman director with a view, perspective, and certain experiences contributed on strategical decision making for issues concerned by the stakeholders.

Feminism is a part of a culture and politic movement that change the women's way of thinking and affect the lifestyle of both gender on interpreting the world (Hannam, 2007: 2). Feminism Care Theory stated that women tend to have a sympathy toward aggrieved groups, thus they tend to have a good moral awareness (Liao et al., 2019; Burkhardt et al., 2020). Women are viewed to have a more caring, compassionate, and aware nature toward social responsibility when compared to (Gull et al., 2018; Gupta et al., 2020; Umer et al., 2020). The policies decreed by woman director are hoped to shape a more positive attitude to the stakeholders (Cook and Glass, 2018) because women play an important role on the decision making process and the controlling actions toward it.

A company is assessed as good if it has a good corporate governance marked by a variety of the board's member, better than when it consisted exclusively of men. Wikhamn \& Wikhamn (2020) in their research found that a homogeny configuration of the member (men only) tends to produce an oblivion decisions due to a certain condition where they feel redundant to coin bigger ideas for the sake of avoiding conflicts. The condition is called groupthink. Vice versa, a more varied configuration may produce a more flexible ideas, as women may act as mediators or ice breaker.

Directors' board is the most affecting party on determining strategies, targets, and decisions of the firm. Women on board tends to generate a varied ideas and innovation in a broader scope that result on a good quality of decisions made both individually and groups (Mirza et al., 2020). Thus the hypothesis:

$\mathrm{H}_{3}$ : Women on boards has a significant effect to the firm value

Carbon emission disclosure is a factor that may affect the value of a company. Women's role in the director's board may manage the greenhouse effect's impacts through the disclosure of such information. A heterogenic group may create an atmosphere where such great communications and considerations on many perspectives exist. Such conditions will stimulate a more proactive discussions of the solutions for the task of disclosing carbon emission.

Olthuis \& Oever (2020) found that women's participation in the directors' board affects the increase of communication's effectiveness between the directors and investors. Women as directors will give a tighter control and maintaining communication of both parties through a more transparent ecological disclosure. Feminism Care Theory 
stated that women have a more caring, compassionate, and aware natured on the social responsibilities than men (Gull et al., 2018; Umer et al., 2020). The women's existence in the directors' board is hoped to create a more conducive condition and increase the board's performance when it comes to discipline and concentration (Gupta et al., 2020).

Farida (2019) stated that stakeholder theory may be able to explain that the attendance of women in the board of directors potentially generates more innovative and transparent decisions. Women are able to push the company in line to the stakeholder's advantage by managing and recommending behaviours, structures, and practices that are done collectively, which shaped the philosophy of stakeholder management (Utomo, 2019 dan Jizi, 2017). Social role theory also stated that the variations in the directors' board will produce a good quality in making decisions due to a varied views, networks, and backgrounds, which will satisfy stakeholder's contraring needs (Nadeem et al. (2017), Cook \& Glass, 2018, Liao et al., 2019).

Women generally have a different demography that depicts the social economy environments on a several scopes (Lee \& Xiao, 2020; Amorelli \& García-Sánchez, 2020). Women on board also help the firm to understand their environment to meet the stakeholders' needs. Planning, Organizing, and Controlling activities that are conducted by the women directors are hoped to produce a carbon emission disclosure so that the firm value will tend to increase.A harmonic relationship with the stakeholders can be seen through the firm value. Thus the hypothesis:

$\mathrm{H}_{4}$ : Carbon Emission Disclosure Mediates the relationship of women on boards and firm value.

\section{Research Method}

This research population consist of the entire companies registered in Indonesia Stock Exchange (IDX) on the period between 2015-2019. The sampling requirement is the company should be of non financial one as they generate a big amount of carbon emission. The company is also from the one that produced annual report and finansial statements (audited) from the period stated, and the statements are provided in Indonesian Rupiah. The company should have at least one policy about the carbon emission or store one item of carbon emission disclosure. The data was analyzed using path analysis.

The scope of the item on the carbon emission disclosure is measured by the indeks developed by Choi et al. (2013) constructed from the Carbon Disclosure Project (CDP). Carbon emission disclosure index is proved on Table 1.

If the company has done the disclosure which the items required are met, then it will get 1 point, otherwise it will given 0 score. Then the score of 1 is added up as a whole and divided by the maximum number of items that can be disclosed and then multiplied by $100 \%$. Thus, the carbon emission disclosure formula developed in this study is as follows:

$$
\mathrm{CED}=\left(\frac{\Sigma \mathrm{di}}{\mathrm{M}}\right) \times 100 \%
$$

Information:

$$
\begin{array}{ll}
\mathrm{CED} & =\text { carbon emission disclosure } \\
\Sigma \mathrm{di} & =\text { total of the entire } 1 \text { score by the company } \\
\mathrm{M} & =\text { total of maximal items exposable (18 items) }
\end{array}
$$


Monica, Daromes \& $\mathbf{N g}$

Women on Boards as a Mechanism to Improve Carbon Emission Disclosure and Firm Value

Table 1. Carbon Emission Disclosure Index

\begin{tabular}{|c|c|}
\hline Variable & Indicator \\
\hline $\begin{array}{l}\text { Climate } \\
\text { Change Risks } \\
\text { and } \\
\text { Opportunities }\end{array}$ & $\begin{array}{l}\text { CC1 - Assesment/Description of the risks related to the climate } \\
\text { change and the actions done or to be done toward them } \\
\text { CC2 - Assesment/Description of present (and future) implications on } \\
\text { financial, business, and opportunities by the climate change }\end{array}$ \\
\hline $\begin{array}{l}\text { Greenhouse } \\
\text { Gas } \\
\text { calculations }\end{array}$ & $\begin{array}{l}\text { GHG1 - Description on methodology used to calculate Greenhouse } \\
\text { Gas Emission } \\
\text { GHG2 - Verification and external parties existence on GHG emission } \\
\text { measurement } \\
\text { GHG3 - Total of GHG emission generated } \\
\text { GHG4 - Scope } 1 \text { and } 2 \text { Disclosure, or Scope } 3 \text { of the GHG emission } \\
\text { GHG5 - GHG Emission source disclosure } \\
\text { GHG6 - GHG segmentation or facilities disclosure } \\
\text { GHG7 - GHG Emission annual comparisons. }\end{array}$ \\
\hline $\begin{array}{l}\text { Energy } \\
\text { Consumption }\end{array}$ & $\begin{array}{l}\text { EC1 - Total of energi consumed } \\
\text { EC2 - Quantification of energi used from renewable resources } \\
\text { EC3 - Type, Facilities, or segment based disclosures }\end{array}$ \\
\hline $\begin{array}{l}\text { costs and } \\
\text { GHG } \\
\text { reductions }\end{array}$ & $\begin{array}{l}\text { RC1 - Detail of plans or strategies to reduce GHG Emissions } \\
\text { RC2 - Specifications of GHG emissions reduction target level and } \\
\text { target year } \\
\text { RC3 - Emission reductions and associated costs or savings achieved } \\
\text { to date as a result of the reduction plan } \\
\text { RC4 - Cost of future emissions factored into capital expenditure } \\
\text { planning }\end{array}$ \\
\hline
\end{tabular}

5. carbon ACC1 - indication of which board committee has overall emissions responisibility for actions related to climate change

accountability ACC2-description of the mechanism by which the board reviews the firm's progress regarding climate change

Source: Choi et al. (2013)

The value of the firm used in the research is measured by Tobin's $Q$ modified by Gaio \& Raposo (2011) in the form of Simple Q. The advantage of this measurement is that it can depict a firm's assets value in the entirety and answers to the difficulties on estimating market value of debt and replacement costs. The usage of this measurement tool has been used by several researches : Kelvin et al. (2017), Hung \& Van (2020), and Dang et al. (2020). The equation of Simple $Q$ is as follows:

$$
Q_{i t}=\frac{B V A_{i, t}+M V E_{i, t}-B V E_{i, t}}{B V A_{i, t}}
$$

Information:

$\mathrm{Q}_{\mathrm{i}, \mathrm{t}} \quad=$ value of Tobin's $\mathrm{Q}$ for firm i on year $\mathrm{t}$

$\mathrm{BVA}_{\mathrm{i}, \mathrm{t}} \quad=$ book value of total assets for firm i on year $\mathrm{t}$

$M V E_{i, t} \quad=$ market value of the equity for firm $\mathrm{i}$ on year $\mathrm{t}$

$B V E_{i, t}=$ book value of the equity for firm $i$ on year $t$ 
Women on boards is the representative of women held role in the director's board. The measurement of the women on boards on the research of Lori et al. (2019). It is as follows:

$$
\text { Women on Boards }=\frac{\text { amount of women on directors' board }}{\text { Total of the directors'board members }}
$$

\section{Result and Discussion}

The population in this study are non-financial companies listed on the Indonesia Stock Exchange (IDX) in 2015 to 2019. Sampling was done by the purposive sampling method based on criterias provided on Table 2 .

Firms that fulfill the sample criterias for each year are counted to 122 or 610 analysis unit. The analysis bear the result of the SPSS v.20 software processing that out of 610 data, there is an indication of 205 data with outlier (Z-score $\pm 1,96)$, which won't be used further in the research. Outlier is when the data has a unique character and appears on extreme value, would it be a single or combined variable. The amount of outlier data is due to unavoidable extreme data taken from population that doesn't have a normal distribution. This is showed on the result of the measurement of women on board and the carbon emission disclosure done by the author. It was done unevenly by the firms taken as samples, whether one firm disclosed the whole item or just 1-2 item(s), thus such extremity is taken as outlier and won't be included in the research. By then, the whole samples total are counted to 405 analysis units.

Normality test is to examine whether a residual variable normally distributed on the regression model. A regression model should have a normally distributed residual value. Statistic analysis can be used is the non parametric Kolmogorov-Smirnov (K-S). A regression has normal residual data distribution if the K-S examination bears a significancy higher than 0,05 or $5 \%$ (Ghozali, 2018). The normality test result are provided below:

The normality test result of model 1 and 2 has a significancy value of more than 0,05 so it was concluded that the data tend to be normally distributed and both of the models are qualified to be examined furtherly.

Descriptive statistic analysis was done to analyze and provide quantitive data for the sake of knowing the firm made as sample in its entirety, down to the mean, maximum or minimum value, and standard deviation of the variables observed.

Women on boards shows the lowest value of 0,000 and the highest of 0,429 . The mean of the variable is 0,175 . Standard deviation which shows the gender variety in the firm counts to 0,138 . This shows that $17,5 \%$ of the observed samples are the firms with women on the directors' board. The women on the directors' board is still on a little value at the samples observed.

Table 2. Research Samples

\begin{tabular}{clc}
\hline No. & \multicolumn{1}{c}{ Criteria } & Total \\
\hline 1 & Population & 447 \\
2 & Financial Firms & $(80)$ \\
3 & Firms that were not listed continually through 2015-2019 & $(4)$ \\
4 & Firms with USD currency stated financial statements & $(61)$ \\
5 & Firms that don't disclose their carbon emission & $(180)$ \\
\hline & Total Samples & 122 \\
\hline
\end{tabular}

Source: Processed Data, 2020 
Monica, Daromes \& $\mathbf{N g}$

Women on Boards as a Mechanism to Improve Carbon Emission Disclosure and Firm Value

Table 3. Normality Test Result

\begin{tabular}{cccccc}
\hline $\begin{array}{c}\text { Independent } \\
\text { Variables }\end{array}$ & $\begin{array}{c}\text { Dependent } \\
\text { Variables }\end{array}$ & Model & $\begin{array}{c}\text { Kolmogorov- } \\
\text { Smirnov Z }\end{array}$ & Sig. & Result \\
\hline WOB & COE & 1 & 1.290 & 0.072 & Normal distribution \\
WOB & FV & 2 & 0.974 & 0.298 & Normal distribution \\
COE & & &
\end{tabular}

WOB $=$ Women on Boards, $\mathrm{CED}=$ Carbon Emmission Disclosure, FV = Firm Value

Source: Processed data, 2020

The lowest and highest value of Carbon Emission Disclosure 0,056 dan 0,333 with the average mean of 0,178 and standard deviation of 0,081 . This shows a little awareness of the Indonesian firms on exposing the informations of their carbon emission as averagely they only reported 2-3 items out of the entire 18 items of the carbon emission disclosure indeks. The standard deviation that somehow is smaller than the mean value shows that the data deviation is narrower, and indicates of the data spreads.

The lowest and highest value of Firm Value 0,120 dan 2,031, with the average mean and standard deviation alternately counts to 0,997 dan 0,443 . This means an average of Indonesian firms value are almost good as it closer to 1 , which indicates a good management of the firms.. The standard deviation that somehow is smaller than the mean value shows that the data deviation is narrower, and indicates of the data spreads.

The relationship pattern between the three variables will be examined by the pattern analysis, which of the coefficient is taken from the standarized regression coefficient as such presented in the Table 5.

Women on boards has a positive and significant effect on Carbon Emission Disclosure by the positive pattern coefficient of 0,320 and $p$ value of 0,000 . Women on boards and Carbon Emission Disclosure has a positive effect on the firm value. The effect of women on boards to the firm value generates a positive pattern coefficient value of 0,074 and $p$ value of 0,137 . This shows that women on boards positively affect but not significant to the firm value. The effect of Carbon Emission Disclosure to the firm value results on positive pattern coefficient value of 0,305 and $p$ value of 0,000 . This shows a positive and significant effect of Carbon emission disclosure to the firm value.

Sobel Examination is also done on the research to examine the indirect effect of the free variable to the bond variable through the mediating variable. Sobel test result bears $p$-value of $0,000<0,05$ which shows the CED mediating the women on boards to the firm value.

The result of the research shows women on boards has a positive and significant effect to the CED by the positive pattern coefficient of 0,320 and $p$ value of 0,000 . This research shows statistically the more women on the directors' board, the more of the CED wil be reported. Thus the first hypothese approved.

The result of the research is in line with the research conducted by Liao et al. (2015) which founds the gender variety has a significant positive effect on the CED. Yet, it

Table 4. Descriptive Statistic Result

\begin{tabular}{lcllcc}
\hline \multicolumn{1}{c}{ Variable } & $\mathrm{N}$ & Min & Max & Mean & Std. Deviation \\
\hline Women on Boards (WOD) & 405 & 0.000 & 0.429 & 0.175 & 0.138 \\
Carbon Emission Disclosure (CED) & 405 & 0.056 & 0.333 & 0.178 & 0.081 \\
Firm Value (FV) & 405 & 0.120 & 2.031 & 0.997 & 0.443 \\
\hline
\end{tabular}

Source: Processed Data, 2020 
Monica, Daromes \& $\mathbf{N g}$

Women on Boards as a Mechanism to Improve Carbon Emission Disclosure and Firm Value

Table 5. Standardized Value Pattern Coefficient

\begin{tabular}{|c|c|c|c|}
\hline Model & $\begin{array}{l}\text { Estimated } \\
\text { Coefficient }\end{array}$ & $P$ & Notes \\
\hline \multicolumn{4}{|l|}{ Model 1} \\
\hline \multicolumn{4}{|l|}{ The Effect of Women on Boards on Carbon } \\
\hline Emission Disclosure & 0.320 & 0.000 & Significant \\
\hline \multicolumn{4}{|l|}{ Model 2} \\
\hline $\begin{array}{l}\text { The Effect of Women on Boards on Firm } \\
\text { Value }\end{array}$ & 0.074 & 0.137 & unsignificant \\
\hline $\begin{array}{l}\text { The Effect of Carbon Emission Disclosure } \\
\text { on Firm Value }\end{array}$ & 0.305 & 0.000 & Significant \\
\hline
\end{tabular}

Source: Processed Data, 2020

contradicted the one by Tingbani et al. (2020) which stated that the said variable doesn't effect positively nor significantly to the CED.

The stakeholder theory stated that the directors or the management of the company have to put concern on the parties or larger group but the stockholders. Women tend to have a capability in facilitating the spread of the information, so by the women on boards, the firm is hoped to produce a more broad and transparent carbon emission disclosure (Birindelli, 2020). Women in expressing their feelings use such superlative phrases, metaphores, or generalizations which came from their caring nature, even if it means their own sacrification (Gray, 1993). The women on board varies the gender composition which lead to a more varaied knowledges, characters, and innovations on the ecology aspect.

The existence of the company is heavily independent to its stakeholders (Hitipeuw \& Kuntari, 2020). To gain their support, a consideration on a social and environmental disclosure needs to be done as the responsibility of resources usages from the firm activities, one of them is the Carbon Emission Dsiclosure, which at sometimes doesn't always get in line with the firm goals. A woman leader with a higher moral awareness will produce a qualified disclosure, and vice versa (Solikhah, 2020).

The result of the research found that women on boards has a positive and significant effect to the CED, which indicates that women are more caring on the life quality rather than material achievements so that their existence on the board of directors may produce a qualified CED. A motherly character of a woman is viewed to be able to bring a more better quality change to the company on the scope of gender, life quality, and sustainability aspect. Thus it balances the profit oriented and non-profit moral awareness of the firm.

The result of the examination on the effect of women on boards to the firm value shows a high regression coefficient of 0,074 and significancy probability of $0,137>0,05$ which shows that women on boards has a positive but not significant effect to the firm value thus the Hypothese $2\left(\mathrm{H}_{2}\right)$ is stated as Rejected.

Table 6. Sobel Test Result

\begin{tabular}{|c|c|c|c|c|}
\hline Annotation & $\begin{array}{l}\text { Estimate } \\
\text { d Value }\end{array}$ & $\begin{array}{c}\text { Standard } \\
\text { Error }\end{array}$ & $\begin{array}{l}p \text { value of } \\
\text { sobel test }\end{array}$ & Annotation \\
\hline $\begin{array}{l}\text { The effect of Women on Boards to } \\
\text { the firm value through the carbon } \\
\text { emission disclosure }\end{array}$ & $\begin{array}{c}0,189 ; \\
1,660\end{array}$ & $\begin{array}{l}0,028 \\
0,270\end{array}$ & 0,000 & Significant \\
\hline
\end{tabular}

Source: Processed data, 2020 
Monica, Daromes \& $\mathbf{N g}$

Women on Boards as a Mechanism to Improve Carbon Emission Disclosure and Firm Value

Table 7. Examination on Hypotheses

\begin{tabular}{lc}
\hline \multicolumn{1}{c}{ Variables } & $\begin{array}{c}\text { Hypotheses test } \\
\text { result }\end{array}$ \\
\hline $\mathrm{H}_{1}:$ Effect of women on boards to CED & Approved \\
$\mathrm{H}_{2}:$ The Effect ofwomen on boards to Firm Value & Rejected \\
$\mathrm{H}_{3}$ : The Effect of CED to the Firm Value & Approved \\
$\mathrm{H}_{4}$ : CED mediated the relationship of women on boards to Firm & Approved \\
Value & \\
\hline
\end{tabular}

Source: Processed data, 2020

The result of the observation contradicted the research of Orazalin \& Baydauletov (2020) which stated that the women on boards has a significant effect on firm value. women on boards propels a more varied ideas and innovation on a larger scope for a better decision making process, individually or collectively (Mirza et al., 2020). The result of the observation also differed from the one of Orazalin \& Baydauletov (2020) which supports the varied gender increase the company's competitive advantage which will affect the firm value.

The existence of the company is heavily independent to its stakeholders (Hitipeuw \& Kuntari, 2020). Positive traits of women may gain a plus point to the firm value, as they tend to make decisions which not only to bring profit, but also to minimize the negative effect on stakeholder parties.

Wikhamn \& Wikhamn (2020) stated that heterogen directors board member may take a more flexible ideas by the attendance of women members as the mediators be it on uncondusive conditions. High ethical standards also avoid women from negative deeds such as profit manipulations, so they tend to be more careful and into a more qualified work standard, which will gain the interest from the investors (Martínez \& Rambud, 2019).

The result of the research shows women on boards effect positively but not significant to the firm value. There is an indication that women tend to choose to manage firm activities rather than its assets and liabilities as the last two are able to be measured accountably, which by the womens are so beyond the obedience to the rules, as they are more interested in creating a more qualified company's performance.

Carbon emission disclosure has effected the firm value by the regression coefficient of 0,305 dan significancy probability value of 0,000 . Which shows the positive and significant effect on the firm value by the CED. Thus Hypothese $3\left(\mathrm{H}_{3}\right)$ is stated to be Approved.

The result of this study is in line with the research conducted by Yang et al. (2020) and Alsaifi et al. (2020) which states that carbon emissions disclosure has a positive effect on firm value. Alsaifi et al. (2020) revealed that increasing the carbon emissions disclosure will increase the value of the company on the shares traded by the company. Voluntary disclosure of climate change-related information disclosed by companies in annual reports and sustainability reports will be of added value for companies that can attract investors to invest. However, Downar et al. (2020) found different results where carbon emission disclosure had an impact on the decline in company value which was proxied through the book value of assets. In certain cases, such as the inefficient use of company machines and vehicles, investors make the carbon emission disclosure resulting from the company's operational activities as bad news that can worry about the potential costs faced by the company to overcome the environmental impacts caused so that companies 
try not to disclose information about operations that produce high carbon emissions so that the company's reputation remains good in the eyes of investors.

High firm value is realized through the fulfillment of the company's carbon emission disclosures. Yang et al. (2020) states that companies will voluntarily disclose carbon information to gain trust and fulfill stakeholder demands or build an image by committing to reduce carbon emissions. Disclosure of the types of carbon emission sources owned by the company such as equipment, vehicles, and machinery will provide benefits for management in determining the optimal asset management strategy.

A company that successfully makes quality social and environmental disclosures will give the effect on the value of the company (Kelvin et al., 2019). This is in line with stakeholder theory which states that a good company will build a code of ethics that is not only concerned with the interests of shareholders but also pays attention to the welfare of its stakeholders (Freeman \& Reed, 1983). Disclosure of the total energy consumed and quantification of the use of renewable energy as a form of carbon emissions disclosure will provide greater benefits for the survival of natural ecosystems and the lives of present and future generations. Thus, the carbon emissions disclosure can be a sign of seriousness for stakeholders that the company is trying to be efficient because it has commitment and concern for the environment (Jaggi et al., 2018).

Carbon emissions disclosure is also an expression of respect and the company's efforts to always remind the need to maintain and preserve all living systems on this earth. Lovelock \& Watson (1982) in Gaia theory states that the living system on earth has issued a 'red light' or an alarm that the earth's immune system has approached the threshold. The high content of $\mathrm{CO}_{2}$ and other greenhouse gases in the atmosphere is no longer able to be rapidly reduced by all plants and phytoplankton on earth today. Therefore, carbon emissions disclosure reductions can be used as a sign of the company's seriousness in contributing to maintaining and maintaining the stability of the earth's homeostasis system. This information on the company's carbon emissions will increasingly attract the attention of capital market players so that it can be used to analyze company value ( $\mathrm{Ng} \&$ Daromes, 2016; Rashid, 2018).

Carbon emissions disclosure allows investors to identify potential risks to a company's future performance and evaluate alternative strategies to meet the challenges associated with those risks. The high level of corporate disclosure also gives a message that the company's carbon management activities are related to better economic performance because the efficiency carried out such as replacing old energy-consuming equipment can result in better company performance. Thus, carbon emissions disclosure will encourage investors to assess the company's operational value through the identification of sustainable management practices that will result in higher company value.

The results of this study indicate that women on boards have a significant effect on the carbon emissions disclosure, and carbon emissions have a significant effect on firm value. The results of the Sobel test also stated that there was a significant effect of the independent variable, namely women on boards, on the value of the company through the carbon emissions disclosure. Thus, Hypothesis $4\left(\mathrm{H}_{4}\right)$ which states that carbon emissions disclosure mediates the relationship between women on boards and firm value is approved.

Carbon emissions disclosure is assessed through several disclosure indices, namely disclosure of information on risks and opportunities from climate change, 
calculation of greenhouse gas emissions, total energy consumed by companies, costs and strategies for reducing greenhouse gas emissions, and accountability for carbon emissions. Carbon emissions disclosure is one of the factors that can affect the increase in company value. The role of women on the board of directors can prove their skills in managing greenhouse gases the best that companies do through carbon emissions disclosure. The presence of women in council groups that were previously homogeneous into heterogeneous can create conditions in which there is greater communication and consideration of multiple perspectives. This condition is then able to stimulate a more proactive discussion of various solutions to the task so as to produce high quality carbon emission disclosures that can stimulate an increase in company value.

Utomo (2019) states that stakeholder theory is related to management and recommends attitudes, structures and practices that are carried out together to form a stakeholder management philosophy. Every company is expected to have awareness to protect and preserve the environment which is not solely for the benefit of humans, but is part of the responsibility of the cosmic system of global life on earth (Lovelock, 1979). The planning, organization and supervision carried out by the female board of directors in stakeholder management are strived to be able to carry out the carbon emissions disclosure so that the value of the company tends to increase. Harmonious relationships with stakeholders can be seen through the value of the company because companies with high values will be seen as transparent in disclosing carbon emissions.

Gray (1993) states that women value feelings, communication, and relationships which make women very intuitive where they are able to anticipate the needs of others without being asked. Characteristics of women will result in better disclosure quality because women tend to be more oriented to aspects of life because of the maternal instinct inherent in a woman so that her contribution is not only on the gender aspect but more on the quality of life aspect, especially the quality of the earth where the company is located. Understanding, trust, and support provided by stakeholders motivate women to make disclosures on carbon emissions that arise as a result of company activities.

Olthuis \& Oever (2020) found that the participation of women on the board of directors has an impact on increasing the effectiveness of communication between the board of directors and investors. The presence of female directors provides tighter control and maintains communication between directors and investors through more transparent disclosure of the environment. The presence of women on the board of directors has an advantage over all male boards of directors because women are able to create a conducive atmosphere with their ability to solve problems because they consist of various perspectives and can improve the performance of the board with accuracy and discipline in the tasks carried out, so that the presence of women has the effect on decisions. made and able to control the company to make quality carbon emission disclosures.

\section{Conclusion}

The presence of women on the board of directors is able to produce better quality of carbon emission disclosures, but the presence of women is not able to provide a strong effect in increasing firm value. This is because women tend to be more concerned with the quality of life by contributing to the company's activity management process compared to asset and debt management that already has its own standards. 
The results of this study also show that the carbon emissions disclosure plays a role in mediating women on boards on firm value. The increasing condition of the earth's temperature caused by rising $\mathrm{CO}_{2}$ levels is the responsibility of all creatures on earth to jointly preserve the environment (earth) so that it remains livable. The response to the threat posed by climate change has become a worldwide concern and has become an integral part of business. The company does not only disclose but must pay attention to the material value of the impact caused by the company, even if it is necessary to use the metric tons of carbon produced. National Action Plan for Reducing Greenhouse Gases through Presidential Regulation No. 61 of 2011 is a form of Indonesia's commitment to reduce carbon emissions so that people are able to live and avoid various threats of climate change. Therefore, the carbon emission disclosure can be a form of the company's contribution to participate in maintaining the harmony of living systems on earth. The presence of women on the company's board of directors is able to produce better disclosure quality so that their contribution is not only in the gender aspect but also in the quality of life aspect, especially the quality of the earth where the company is located. The characteristics of women tend to be more oriented to aspects of life because the maternal instinct inherent in a woman makes her contribution not only to the company but also to future generations.

The limitation of this research is that the measurement of carbon emission disclosure only comes from annual reports because not all companies issue sustainability reports as another source of environmental disclosure. Therefore, future research should examine the company's carbon performance as measured using the natural logarithm of the intensity of carbon emissions (Luo, 2019) in order to provide evidence that the carbon emission disclosure is not only limited to disclosure as a form of corporate image but high awareness of the company to maintain the balance and sustainability of natural ecosystems.

\section{References}

Ahmad, N. N. N., \& Hossain, D. M. (2015). Climate Change and Global Warming Discourses and Disclosures in the Corporate Annual Reports: A Study on the Malaysian Companies. Procedia - Social and Behavioral Sciences, 172, 246-253. https://doi.org/10.1016/j.sbspro.2015.01.361

Alsaifi, K., Elnahass, M., \& Salama, A. (2020). Carbon disclosure and financial performance: UK environmental policy. Business Strategy and the Environment, 29(2), 711-726. https://doi.org/10.1002/bse.2426

Amorelli, M. F., \& García-Sánchez, I. M. (2020). Critical mass of female directors, human capital, and stakeholder engagement by corporate social reporting. Corporate Social Responsibility and Environmental Management, 27(1), 204-221. https://doi.org/10.1002/csr.1793

Birindelli, G., lannuzzi, A. P., \& Savioli, M. (2019). The impact of women leaders on environmental performance: Evidence on gender diversity in banks. Corporate Social Responsibility and Environmental Management, 26(6), 1485-1499. https://doi.org/10.1002/csr.1762

Burkhardt, K., Nguyen, P., \& Poincelot, E. (2020). Agents of change: Women in top management and corporate environmental performance. Corporate Social Responsibility and Environmental Management, 27(4), 1591-1604. https://doi.org/10.1002/csr.1907 
Byron, K., \& Post, C. (2016). Women on Boards of Directors and Corporate Social Performance: A Meta-Analysis. Corporate Governance: An International Review, 24(4), 428-442. https://doi.org/10.1111/corg.12165

Choi, B. B., Lee, D., \& Psaros, J. (2013). An Analysis of Australian Company Carbon Emission Disclosures. Pacific Accounting Review, 25(1), 58-79. https://doi.org/10.1108/01140581311318968

Cook, A., \& Glass, C. (2018). Women on corporate boards: Do they advance corporate social responsibility?. Human relations, 71(7), 897-924. https://doi.org/10.1177/0018726717729207

Dang, H. N., Pham, C. D., Nguyen, T. X., \& Nguyen, H. T. T. (2020). Effects of corporate governance and earning quality on listed Vietnamese firm value. The Journal of Asian Finance, Economics, and Business, 7(4), 71-80. https://doi.org/10.13106/jafeb.2020.vol7.no4.71

Downar, B., Ernstberger, J., Reichelstein, S. J., Schwenen, S., \& Zaklan, A. (2020). The impact of carbon disclosure mandates on emissions and financial operating performance. ZEW-Centre for European Economic Research Discussion Paper, (20-038). https://ideas.repec.org/p/zbw/zewdip/20038.html

Farida, D. N. (2019). The Effect Diversitas Gender Terhadap Pengungkapan Sustainability Development Goals. Jurnal Akuntansi Indonesia, 8(2), 89-107.

Freeman, R. E., \& Reed, D. L. (1983). Stockholders and Stakeholders: A New Perspective on Corporate Governance. California Management Review, 25(3), 88-106. https://doi.org/10.2307/41165018

Gaio, C., \& Raposo, C. (2011). Earnings quality and firm valuation: International evidence*. Accounting and Finance, 51, 467-499. https://doi.org/10.1111/j.1467-629X.2010.00362.x

Ghozali, I. (2018). Aplikasi Analisis Multivariate dengan Program IBM SPSS 25. Semarang: Badan Penerbit Universitas Diponegoro.

Gray, J. (1993). Men are from mars, women are from venus. A Practical Guide for Improving Communication and Getting What You Want in Your Relationships. Harper Collins Publishers.

Gull, A. A., Nekhili, M., Nagati, H., \& Chtioui, T. (2018). Beyond gender diversity: How specific attributes of female directors affect earnings management. The British Accounting Review, 50(3), 255-274. https://doi.org/10.1016/j.bar.2017.09.001

Gupta, V. K., Mortal, S., Chakrabarty, B., Guo, X., \& Turban, D. B. (2020). CFO gender and financial statement irregularities. Academy of Management Journal, 63(3), 802831. https://doi.org/10.5465/amj.2017.0713

Hannam, J. (2007). Feminism. Eangland: Pearson Education.

Hitipeuw, S. D., \& Kuntari, Y. (2020). The Effect Kepemilikan Saham Publik, Profitabilitas, dan Media terhadap Pengungkapan Tanggung Jawab Sosial Perusahaan. Management and Accounting Expose, 3(1), 40-51. https://doi.org/10.36441/mae.v3i1.135

Hollindale, J., Kent, P., Routledge, J., \& Chapple, L. (2019). Women on boards and greenhouse gas emission disclosures. Accounting and Finance, 59(1), 277-308. https://doi.org/10.1111/acfi.12258

Horisch, J., Schaltegger, S., \& Freeman, R. E. (2020). Integrating stakeholder theory and sustainability accounting: A conceptual synthesis. Journal of Cleaner Production, 275, 124097. https://doi.org/10.1016/J.JCLEPRO.2020.124097 


\section{Monica, Daromes \& $\mathbf{N g}$ \\ Women on Boards as a Mechanism to Improve Carbon Emission Disclosure and Firm Value}

Hung, D. N., \& Van, V. T. T. (2020). Researching the Firm Characteristics Affecting the Earnings Quality: The Case of Vietnam. Calitatea, 21(179), 106-112.

Jaggi, B., Allini, A., Macchioni, R., \& Zampella, A. (2018). Do investors find carbon information useful? Evidence from Italian firms. Review of Quantitative Finance and Accounting, 50(4), 1031-1056. https://doi.org/10.1007/s11156-017-0653-x

Jizi, M. (2017). The Influence of Board Composition on Sustainable Development Disclosure. Business Strategy and the Environment, 26(5), 640-655. https://doi.org/10.1002/bse.1943

Kelvin, C., Daromes, F. E., \& Ng, S. (2017). Pengungkapan Emisi Karbon sebagai Mekanisme Peningkatan Kinerja untuk Menciptakan Nilai Perusahaan. Dinamika Akuntansi, Keuangan Dan Perbankan, 6(1). https://www.unisbank.ac.id/ojs/index.php/fe9/article/view/5948

Kelvin, C., Pasoloran, O., \& Randa, F. (2019). Mekanisme Pengungkapan Emisi Karbon dan Reaksi Investor. Jurnal Ilmiah Akuntansi Dan Bisnis, 14(2), 155-168. https://doi.org/10.24843/jiab.2019.v14.i02.p02

Lee, G., \& Xiao, X. (2020). Voluntary engagement in environmental projects: Evidence from environmental violators. Journal of Business Ethics, 164(2), 325-348. https://doi.org/10.1007/s10551-018-4074-0

Liao, L., Luo, L., \& Tang, Q. (2015). Gender Diversity, Board Independence, Environmental Committee and Greenhouse Gas Disclosure. British Accounting Review, 47(4), 409-424. https://doi.org/10.1016/j.bar.2014.01.002

Liao, Z., Zhang, M., \& Wang, X. (2019). Do female directors influence firms' environmental innovation? The moderating role of ownership type. Corporate Social Responsibility and Environmental Management, 26(1), 257-263. https://doi.org/10.1002/csr.1677

Lori, H., Hamdan, A. M., Sarea, A., \& Al Shirawi, T. M. (2019). Women on board and firm performance: evidence from kingdom of Bahrain. In Handbook of Research on Women in Management and the Global Labor Market (pp. 312-335). IGI Global. https://doi.org/10.4018/978-1-5225-9171-9.ch016

Lovelock, J. E. (1979). Gaia: A New Look at Life on Earth. Oxford University Press: Oxford.

Lovelock, J. E., \& Watson, A. J. (1982). The regulation of carbon dioxide and climate: Gaia or geochemistry. Planetary and Space Science, 30(8), 795-802. https://doi.org/10.1016/0032-0633(82)90112-X

Luo, L. (2019). The influence of institutional contexts on the relationship between voluntary carbon disclosure and carbon emission performance. Accounting \& Finance, 59(2), 1235-1264. https://doi.org/10.1111/acfi.12267

Martínez, M. D. C. V., \& Rambaud, S. C. (2019). Women on corporate boards and firm's financial performance. In Women's Studies International Forum, Vol. 76, 102251. https://doi.org/10.1016/j.wsif.2019.102251

Mirza, N. I., Malik, Q. A., \& Mahmood, C. K. (2020). The value of board diversity in the relationship of corporate governance and investment decisions of pakistani firms. Journal of Open Innovation: Technology, Market, and Complexity, 6(4), 146. https://doi.org/10.3390/joitmc6040146.

Nadeem, M., Zaman, R., \& Saleem, I. (2017). Boardroom gender diversity and corporate sustainability practices: Evidence from Australian Securities Exchange listed firms. Journal of Cleaner Production, 149, 874-885.

https://doi.org/10.1016/j.jclepro.2017.02.141 
Nainggolan, N. E., \& Rohman, A. (2015). The Effect Struktur Corporate Governance Terhadap Pengungkapan Lingkungan (Studi Empiris pada Perusahaan NonKeuangan yang terdaftar di Bursa Efek Indonesia Periode 2011-2013). Diponegoro Journal of Accounting, 4(2), 190-198.

Ng, S., \& Daromes, F. E. (2016). Peran Kemampuan Manajerial Sebagai Mekanisme Peningkatan Kualitas Laba dan Nilai Perusahaan. Jurnal Akuntansi Dan Keuangan Indonesia, 13(2), 174-193. https://doi.org/10.21002/jaki.2016.10

Olthuis, B. R., \& van den Oever, K. F. (2020). The board of directors and CSR: How does ideological diversity on the board impact CSR?. Journal of Cleaner Production, 251, 119532. https://dx.doi.org/10.1016/j.jclepro.2019.119532

Orazalin, N., \& Baydauletov, M. (2020). Corporate social responsibility strategy and corporate environmental and social performance: The moderating role of board gender diversity. Corporate Social Responsibility and Environmental Management, 27(4), 1664-1676. https://doi.org/10.1002/csr.1915

Rashid, A. (2018). Does corporate social responsibility reporting enhance shareholders' value?: A simultaneous equation approach. Journal of Financial Reporting and Accounting, 16(1), 158-178. https://doi.org/10.1108/JFRA-10-2016-0084

Solikhah, B. (2020). Are the Financial Performance and Media Coverage Associated with the Quality of Environmental Disclosures?. KnE Social Sciences, 1255-1265. https://knepublishing.com/index.php/KnE-Social/article/view/6675

Tingbani, I., Chithambo, L., Tauringana, V., \& Papanikolaou, N. (2020). Board gender diversity, environmental committee and greenhouse gas voluntary disclosures. Business Strategy and the Environment, 29(6), 2194-2210. https://doi.org/10.1002/bse.2495

Umer, R., Abbas, N., \& Hussain, S. (2020). The Gender Diversity and Earnings Management Practices: Evidence from Pakistan. City University Research Journal, 10(2), 342-357.

Utomo, M. N. (2019). Ramah Lingkungan dan Nilai Perusahaan. Jakad Media Publishing.

Wikhamn, W., \& Wikhamn, B. R. (2020). Gender diversity and innovation performance: evidence from R\&D workforce in Sweden. International Journal of Innovation Management, 24(07), 2050061. https://doi.org/10.1142/S1363919620500619

Yang, Y., Wen, J., \& Li, Y. (2020). The impact of environmental information disclosure on the firm value of listed manufacturing firms: Evidence from China. International journal of environmental research and public health, 17(3), 916. https://doi.org/10.3390/ijerph17030916

Zsolnai, L. (2006). Extended stakeholder theory. Society and Business Review, 1(1), 3744. https://doi.org/10.1108/17465680610643337 